
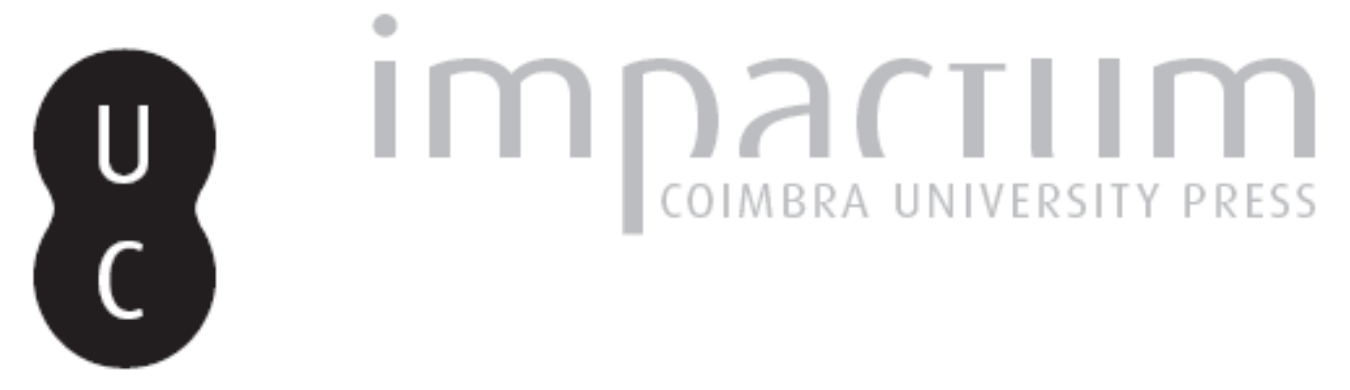

O povo português na obra de João de Barros

Autor(es): João, Maria Isabel

Publicado por: Centro de História da Sociedade e da Cultura

URL persistente:

URI:http://hdl.handle.net/10316.2/39533

DOI:

DOI:http://dx.doi.org/10.14195/1645-2259_10-2_7

Accessed : $\quad$ 26-Apr-2023 13:01:27

A navegação consulta e descarregamento dos títulos inseridos nas Bibliotecas Digitais UC Digitalis, UC Pombalina e UC Impactum, pressupõem a aceitação plena e sem reservas dos Termos e Condições de Uso destas Bibliotecas Digitais, disponíveis em https://digitalis.uc.pt/pt-pt/termos.

Conforme exposto nos referidos Termos e Condições de Uso, o descarregamento de títulos de acesso restrito requer uma licença válida de autorização devendo o utilizador aceder ao(s) documento(s) a partir de um endereço de IP da instituição detentora da supramencionada licença.

Ao utilizador é apenas permitido o descarregamento para uso pessoal, pelo que o emprego do(s) título(s) descarregado(s) para outro fim, designadamente comercial, carece de autorização do respetivo autor ou editor da obra.

Na medida em que todas as obras da UC Digitalis se encontram protegidas pelo Código do Direito de Autor e Direitos Conexos e demais legislação aplicável, toda a cópia, parcial ou total, deste documento, nos casos em que é legalmente admitida, deverá conter ou fazer-se acompanhar por este aviso. 


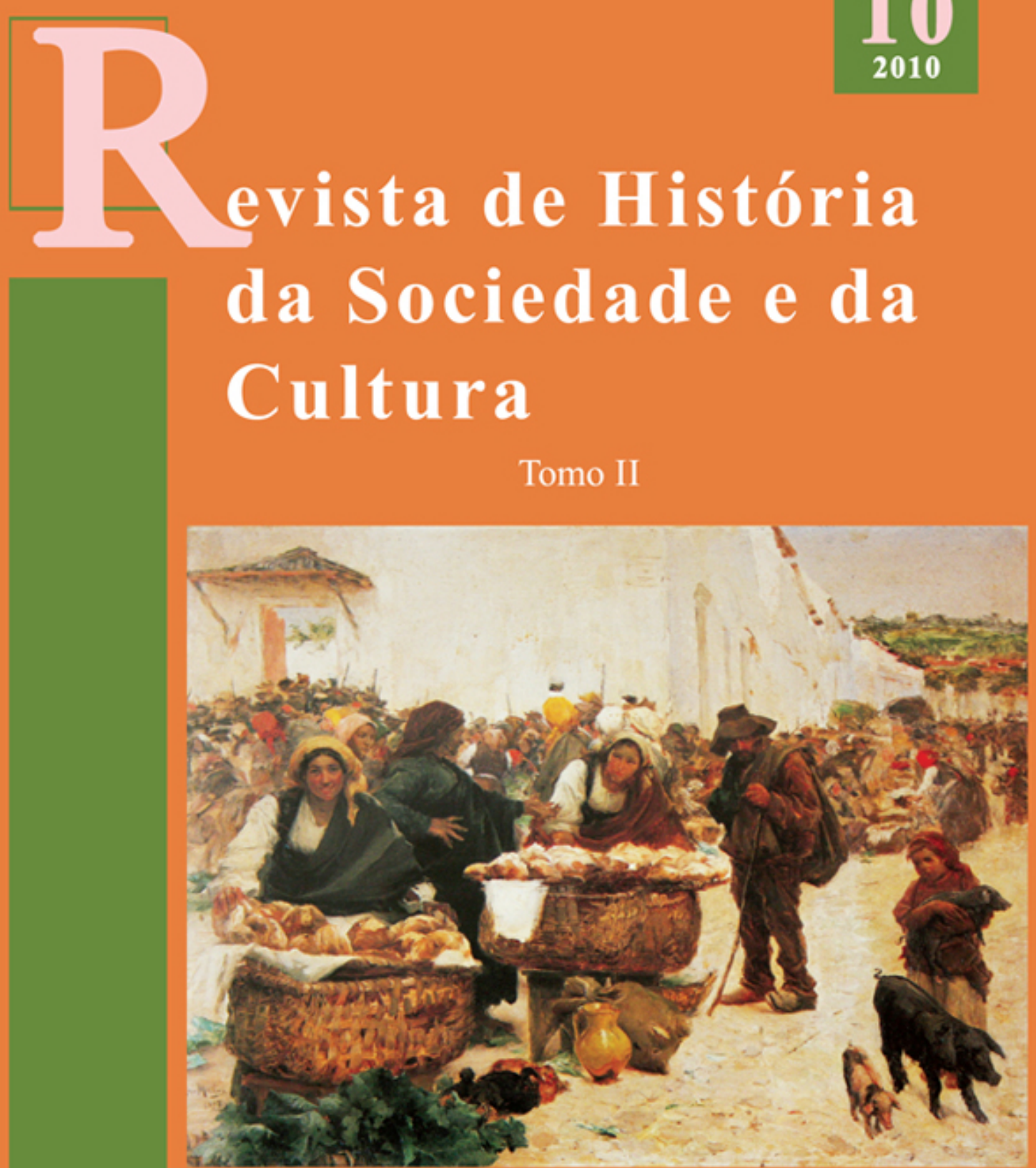

Centro de História da Sociedade e da Cultura Universidade de Coimbra

Coimbra 


\title{
O Povo Português na Obra de João de Barros
}

\author{
Maria Isabel João \\ CEMRI/Universidade Aberta \\ ijoao@univ-ab.pt \\ Texto recebido em/ Text submitted on: 25/02/2010 \\ Texto aprovado em/ Text approved on: 26/05/2010
}

\section{Resumo/Abstract:}

Neste artigo vamos analisar a representação do povo português num autor fundamental para a compreensão do ideário e dos valores republicanos, o escritor e pedagogo João de Barros. Vamos centrar-nos na interpretação de dois textos essenciais sobre esta matéria: uma conferência proferida em 1931, na Voz do Operário, e uma antologia publicada, em 1947, sobre o mesmo assunto que recolhe excertos de textos de variados autores nacionais. Não deixaremos, todavia, de ter como pano de fundo o conjunto da sua obra e a própria vida, dedicada à defesa da instrução pública e da cultura.

In this paper we analyse the Portuguese people as illustrated by the writer and pedagogue João de Barros, essential reading for understanding Republican ideas and values. We focus on the interpretation of two essential texts on this topic: a talk delivered in 1931, at Voz do Operário, and an anthology published in 1947, on the same subject, which is composed of a collection of texts from several national authors. These documents are analysed in the light of the author's complete works and his life, dedicated to defending public education and culture.

Palavras chave/Keywords:

Povo; Representação; Nação.

People; Illustration; Nation. 
Neste artigo vamos abordar a forma como João de Barros imagina o povo português. $\mathrm{O}$ autor foi uma figura cimeira do ideário republicano e é, geralmente, mais conhecido pelas suas ideias no domínio da pedagogia e pela intervenção pública em prol do desenvolvimento da instrução dos Portugueses ${ }^{1}$. Em toda a sua obra o povo é concebido como uma verdadeira força positiva onde as sementes da educação poderiam germinar para se criar um mundo melhor e mais próspero. Porém, há alguns textos onde explana, especificamente, as suas ideias sobre o povo português que têm sido esquecidos nos trabalhos feitos sobre a vida e a produção intelectual de João de Barros. Neles perpassam, a par da visão do autor, representações que eram comuns na época e que continuaram a marcar a forma de imaginar os Portugueses até hoje. Alguns termos caíram em desuso e há formas de dizer as coisas que já não se utilizam, mas na substância a retórica actual sobre o povo, no discurso político e comemorativo, continua a recorrer a estribilhos que encontramos em João Barros e noutros autores que emergiram no quadro da afirmação do nacionalismo, entre o último quartel do século XIX e as primeiras décadas do século XX.

É importante compreender para situar a obra de João de Barros sobre este tema que o povo é um tópico fundamental da construção da identidade nacional. No fundo, trata-se de responder à questão quem somos nós, como colectivo, cujas virtudes e defeitos se inventam e reinventam ao longo das épocas. E podemos remontar longe, pelo menos ao século XVI, à ideia que perpassa na epopeia nacional de Luís de Camões que canta os feitos dos Lusitanos e de nós construiu uma imagem de povo valoroso, às armas feito, capaz de enfrentar os monstros que vivem no fundo do mar e de se espraiar pelo mundo. A sua obra tornou-se uma referência obrigatória no século XIX nos discursos identitários nacionais, no quadro do romantismo e, sobretudo, depois do tricentenário da sua morte no contexto do próprio discurso republicano. A revivescência de que falava Teófilo Braga, tão cara aos que queriam uma mudança do regime político, só podia conseguir-se através do despertar da força e do valor do Povo Português que jaziam adormecidos por um modelo de governação inepto para gerir o país e para conduzi-lo a um futuro à altura do seu passado grandioso. Foi isso, afinal, que se foi

1 REIS, Maria Alice (sel.) - A Pedagogia e o Ideal Republicano em João de Barros. Joaquim Romero Magalhães - Introdução; Lisboa: Terra Livre, 1979. 
expressando ao longo do ciclo comemorativo das grandes descobertas dos Portugueses que decorreu, precisamente, nas últimas décadas de Oitocentos ${ }^{2}$.

Assim sendo, há uma enorme multiplicidade de obras que tratam deste tema de forma directa ou indirecta. Para nos situarmos somente no período da Primeira República e nas duas décadas que se seguem à implantação da Ditadura, num contexto de grande afirmação nacionalista, podemos referir a talhe de foice, de modo nenhum exaustivo, a obra de Teixeira da Pascoes, A Arte de Ser Português (1915), uma edição da "Renascença Portuguesa" que foi um movimento cultural particularmente atento a este tema na sua reflexão sobre o destino de Portugal. Nas páginas da revista Águia e em figuras intelectuais de grande valor, como o médico e historiador Jaime Cortesão, a questão do povo está presente. Bento Carqueja escreveu um opúsculo sobre O Povo Portuguez: Aspectos Sociaes e Economicos (1916) e o problema da origem dos Portugueses motivou diversos estudos, destacando-se A. A. Correia Mendes, Etnologia Ibérica: Considerações Sobre a Origem do Povo Português (1921) e J. Leite de Vasconcelos, Origem Histórica e Formação do Povo Português (1923). Naqueles anos abundaram as palestras e as edições com considerações patrióticas sobre o valor do Povo Português com o intuito explícito de elevar a auto-estima nacional, como hoje se diria, e de contribuir para criar as condições necessárias à obra de transformação nacional que os diferentes quadrantes político-ideológicos pretendiam realizar no país. Deste modo, republicanos democráticos, aderentes do movimento integralista e partidários da Ditadura e do regime do Estado Novo multiplicaram as intervenções sobre a ideia de povo, geralmente no sentido de enaltecer a sua história e de valorizar as qualidades que cada sector ideológico considerava mais úteis para a obra de regeneração nacional que queria ver efectuada em Portugal. Mas o tema também não foi alheio ao discurso dos grupos políticos e sindicais mais minoritários, onde aparece permeado pela ideia da luta de classes e da valorização do povo trabalhador, isto é, dos assalariados e proletários. Entendia-se que nos trabalhadores residia a força

2 Ver sobre o tema: CATROGA, Fernando - "Ritualizações da História" in Luís Reis Torgal, José Amado Mendes e Fernando Catroga - História da História em Portugal Sécs. XIX e XX. Lisboa: Círculo de Leitores, 1996, p. 547-671; JOÃO, Maria Isabel Memória e Império. Comemorações em Portugal (1880-1960). Lisboa: Fundação Calouste Gulbenkian, 2002. 
capaz de mudar a vida miserável dos grupos sociais mais desfavorecidos da sociedade e, em simultâneo, o próprio destino de Portugal como país mais justo e igualitário.

Diríamos que o discurso sobre o povo está no âmago da retórica política contemporânea, porque é em nome dele que se exerce o poder, que se fazem as reformas e as revoluções, que se constroem identidades colectivas e nações. É um assunto praticamente inesgotável, apesar de verificarmos que muitos tópicos se repetem ao longo do tempo e atravessam os vários sectores ideológicos. Por outro lado, é uma temática que tem interessado sobremaneira à propaganda e, nessa linha, se inserem a maior parte das comunicações, mas convém ressaltar o texto de Albino Forjaz Sampaio, Porque me Orgulho de Ser Português (1926), inspirado pela obra do Conde Afonso Celso que deu origem ao "ufanismo" brasileiro. Nele tudo é superlativo e motivo de grande brio nacional: a língua, a terra, as mulheres, as riquezas, o passado histórico e a própria "raça heróica que não tem emula no mundo" . Naturalmente, o Secretariado de Propaganda Nacional, depois Secretariado Nacional de Informação, não podia deixar de valorizar o tema, numa perspectiva histórica, etnográfica e artística. Na revista Panorama e em múltiplas iniciativas culturais e turísticas criaram-se poderosas imagens e símbolos de Portugal e dos Portugueses que marcaram, indelevelmente, o imaginário de várias gerações. Basta pensar na celebrada Exposição do Mundo Português, no âmbito do Duplo Centenário, mas podemos citar pelo menos duas publicações: Vida e Arte do Povo Português (1940), de Francisco Lage, Luís Chaves e Paulo Ferreira, com fotografia de Mário Novais, e alguns anos mais tarde a obra colectiva sobre Portugal: Breviário da Pátria para os Portugueses Ausentes (1946), com prefácio de António Ferro. Nela colaboraram nomes destacados da cultura portuguesa, como Orlando Ribeiro, Marcelo Caetano, Delfim Santos, Luís de Pina, Reinaldo dos Santos. O livro contém mapas, quadros estatísticos, fotografias e índices, numa edição que, não sendo luxuosa, tem inegável qualidade. No ano seguinte, João de Barros publicou a sua antologia sobre O Povo na Literatura Portuguesa, ilustrando deste modo, através de textos respigados de uma

3 SAMPAIO, Albino Forjaz - Porque me Orgulho de Ser Português. Lisboa: Emprêsa Literária Fluminense Lda, 1926, p. 33. 
vasta panóplia de escritores nacionais que se estende por quatro séculos, a sua visão do povo. O projecto não era novo e já tinha sido anunciado numa conferência na Voz do Operário, em 1931, mas só no final dos anos 40 foi dado à estampa pelo autor. $\mathrm{O}$ nosso artigo circunscreve-se à reflexão de João de Barros sobre este tema tão importante naquela época, mas integra-se num projecto mais vasto sobre a ideia de povo na cultura portuguesa contemporânea.

Para situar o autor, importa referir que João de Barros nasceu no seio de uma família burguesa, na Figueira da Foz, em 1881, e morreu em Lisboa, em 1960. Recebeu uma boa educação e cursou Direito na Universidade de Coimbra, onde teve a oportunidade de conviver com figuras que se iriam destacar na vida pública e intelectual, nomeadamente o poeta e pedagogo João de Deus. Depois de uma fase de hesitações naturais no início de uma carreira, João de Barros optou por concorrer ao ensino secundário e começou a ensinar no Liceu Central de Coimbra. Daqui veio para Lisboa e, depois, para o Porto, e, em 1907, graças a uma bolsa de estudos, deslocou-se em missão oficial a vários países da Europa para estudar os respectivos sistemas educativos. Nessa deslocação teve oportunidade de contactar, directamente, com o movimento da Educação Nova e de apreender algumas ideias próprias da pedagogia moderna. Logo no ano seguinte, publicou um livro sobre A Escola e o Futuro, onde relatou com pormenor essa digressão e os ensinamentos que colheu. Numa época de profunda crise social e política, com o regime monárquico em agonia, a mensagem de João de Barros é de confiança na mudança e num futuro melhor através da reforma da instrução pública.

Não admira, por isso, que com a implantação do regime republicano em Portugal, em 1910, ele tenha sido chamado para desempenhar o cargo de Director-Geral da Instrução Pública. Desde os tempos de Coimbra que ele era membro do Partido Republicano e do Grémio Lusitano, um dos principais ramos da maçonaria portuguesa ${ }^{4}$. Nessas funções foi responsável pela elaboração de importantes projectos reformadores que não foram além das boas intenções dos seus proponentes. Todavia, João de Barros continuou

4 ARAÚJO, Alberto Filipe - Barros, João de, in António Nóvoa (dir.) - Dicionário de Educadores Portugueses. Porto: Edições Asa, 2003, p. 139. 
a pugnar pela instrução pública e pela aplicação dos novos preceitos pedagógicos na educação das crianças, através de diversas publicações e de conferências. Em 1913, associou-se ao movimento da Renascença Portuguesa que reuniu uma parte de elite intelectual daquela época. Em termos profissionais, continuou a ser um quadro da administração pública na área do ensino e, com a criação do Ministério da Instrução Pública, voltou a desempenhar funções de chefia. As suas obras sobre a educação republicana, de cunho fortemente ideológico, visavam formar um Homem Novo, pautado por valores laicos, pela crença no progresso, pelo altruísmo e pela solidariedade, bem como pelo equilíbrio entre o desenvolvimento da mente e do corpo. A educação cívica era uma pedra angular do seu projecto educativo, a que associava uma formação moral humanista e uma cultura patriótica que se apoiaria no conhecimento da história da nação.

Apesar do seu optimismo e voluntarismo, João de Barros começou a manifestar o seu descontentamento com a obra da República democrática em matéria de educação. Durante um curto período, já na fase final do regime, foi ministro dos Negócios Estrangeiros, mas não chegou a ter o mesmo cargo na Instrução Pública. Manteve as suas convicções republicanas e democráticas e, com a implantação da Ditadura, acabou por renunciar ao cargo de Director-Geral do Ensino Secundário, voltando a ser somente professor no Liceu Passos Manuel, em Lisboa. Neste esquisso da vida de João de Barros, fundamental para se compreender a sua visão do povo, é importante ainda mencionar a sua profunda ligação ao Brasil, que o levou a publicar em conjunto com o brasileiro Paulo Barreto - que assinava com o pseudónimo jornalístico de João do Rio - a revista Atlântida (1915-1920). No início dos anos Vinte, associou-se ao grupo da Seara Nova e começou a colaborar na revista. Em 1945, colocou-se ao lado das reivindicações públicas do Movimento da Unidade Democrática e apoiou sucessivas candidaturas à presidência da República de oposição ao regime de Salazar. Nas colunas do Diário de Lisboa, "onde colaborou ao longo de quase quarenta anos - não se cansou de dar lições de amor à vida e de estimular o aparecimento de novos valores" . Na sua vasta obra, destacam-se ainda adaptações de textos

5 FERREIRA, David Mourão - Portugal, A Terra e o Homem, Antologia de textos de escritores do século XX. II vol., 1ª série; Lisboa: F. C. Gulbenkian, 1979, p. 27. 
clássicos da literatura para crianças, crónicas e ensaios, livros de viagens e vários volumes de poesia. Uma intervenção pública tão rica, constante e empenhada valeu-lhe o reconhecimento dos seus contemporâneos, manifestado através de condecorações e homenagens públicas.

Os textos que vamos analisar são uma conferência que fez, em 1931, na Sociedade de Instrução e Beneficência "A Voz do Operário", que foi publicada em opúsculo com o título O povo na Literatura Portuguesa e a obra que veio a editar com a mesma denominação. Neste livro reuniu um conjunto variado de textos de autores portugueses, apresentados no seu prefácio. Apesar de esta antologia não estar datada é, normalmente, referenciada como uma obra de 1947. Depois de ter regressado à actividade docente, num contexto em que havia motivos para o pessimismo e a descrença na faculdade dos Portugueses para realizaram a obra de progresso moral, científico, social pela qual tinha lutado toda a vida, João de Barros reagiu procurando mostrar, através de trechos dos escritores portugueses, produzidos ao longo dos séculos, que o povo sempre tinha sido a força "providencial" da nação - o termo é dele ${ }^{6}$. Por isso, do amor do povo português pela liberdade e pela independência, da sua capacidade de combater a tirania e de afirmar o seu patriotismo ingénito ainda podia vir a salvação de Portugal, na visão de João de Barros. Esta última ideia não está expressa, nem poderia estar no ambiente político da Ditadura e do Estado Novo, mas é a ilação lógica das escolhas que fez para a antologia e dos textos da conferência e do prefácio, mais desenvolvido, do livro. Sendo um indivíduo que acreditava na perfectibilidade humana, numa linha de pensamento que remonta ao Iluminismo, João de Barros via no povo português, tal como o idealizava, qualidades congénitas que podiam servir de esteio à obra de mudança da sociedade e da governação.

A primeira questão consiste em perceber o que entende João de Barros por povo. A resposta não é simples, visto que o autor nunca define o conceito. A sua ideia de povo plasma-se no texto de forma difusa, tanto naquilo que escreve como nos trechos que escolhe para a antologia. Por isso, temos de fazer várias aproximações do problema e procurar elucidar

6 BARROS, João de (selecção e prefácio) - O Povo na Literatura Portuguesa. Lisboa: Guimarães \& C. ${ }^{a}$, [1947], p. 7 (doravante: PLP). 
os vários ângulos da sua abordagem. O povo define-se por oposição ao que chama as "classes dirigentes", as quais são as portadoras dos vícios e da decadência da sociedade portuguesa. Por isso, do povo fazem parte os "humildes" e com ele se confundem todos aqueles que, apesar de serem educados e abastados, não têm uma atitude arrogante e sabem interpretar nos seus textos os sentimentos populares. Vários dos escritores cujos trechos escolhe para a antologia são apresentados desta forma, como indivíduos que representam o povo ou são legítimos herdeiros dele. A humildade está associada a uma vida simples, austera e à pobreza que é uma característica da maior parte do povo. Deste modo, vemos desfilar uma galeria de tipos sociais que começam no pobre escudeiro enamorado do teatro vicentino e se estendem por variadas actividades retratadas de forma mais naturalista ou realista, consoante os autores da antologia: o lenhador, o mineiro, o pastor, os ceifeiros, os pescadores, os vindimadores do Douro. Todos eles têm em comum as condições duras da existência que, não obstante, não lhes retiram a humanidade e a capacidade de sofrimento. No poema de Cesário Verde, vemos esses grupos compostos por famílias inteiras que debandam das suas terras em busca de trabalho: jornaleiros, ganhões, trabalhadores, que se oferecem em praças aos domingos para ganhar o parco sustento, tal como o gado é vendido nas feiras. E o poeta António Nobre não esconde um arrepio de nojo perante as misérias, as pústulas, os aleijados que pedem esmola "p'las alminhas das suas obrigações!": "pelo nariz corre-lhes pus, gangrena, ranho! / E, coitadinhos! Fedem tanto: é de arrasar..."7.

Esse povo evocado a cada página é bem digno descendente do Cristo que morreu pregado na cruz, como recorda Antero de Quental num soneto. Porém, não se trata da Plebe passiva, amedrontada e incapaz de reacção perante a desgraça. Não!, aqueles que o poeta considera herdeiros do" sangue generoso" de Jesus são os que lutam: "Do pobre que protesta foste a imagem / Um povo em ti começa, um homem novo" . O povo assume a dimensão do herói colectivo e é o principal actor da epopeia nacional, lavrada em verso por Luís de Camões. A virilidade, a coragem, a audácia, a bravura no campo militar são apanágio do povo português que se distingue contra os invasores

\footnotetext{
NOBRE, António - Lusitânia no Bairro Latino in PLP, p. 184.

${ }^{8}$ QUENTAL, Antero de - A um Crucifixo in PLP, p. 130.
} 
espanhóis, contra as tropas napoleónicas ou nas várias frentes de batalha, na Europa e na África. O povo é viril e, se não pode brandir as espadas, agita os cacetes e usa de todas as manhas para vencer os inimigos. Neste aspecto, mesmo as mulheres invocadas são a padeira de Aljubarrota, embora o escritor Camilo Castelo Branco não pense que matar sete espanhóis bêbados, feridos ou exaustos seja um feito de louvar'. Mais notável foi a coragem de outra mulher que soube enfrentar os soldados que vinham para a violar ou a força da Maria da Fonte que o historiador Oliveira Martins considera uma espécie de Joana d'Arc portuguesa ${ }^{10}$. Natural da província do Minho, como as suas conterrâneas tem a dureza de um homem na forma como é capaz de enfrentar os atritos da vida rude e cruel. De resto, a comparação de Oliveira Martins não é muito apropriada, porque estas duas figuras legendárias são muito diferentes. Só as irmana o facto de terem pegado em armas para combater.

No discurso de João de Barros, o povo pode assumir várias dimensões geográficas e sociais, consoante o contexto. Porém, de modo geral, o povo que tem em mente é aquele que forma a nação portuguesa, o qual quer surpreender nas suas múltiplas facetas e enaltecer através desta antologia de "carácter nitidamente patriótico"11. Por isso, como era comum na época em que escreveu, usa também o termo "raça" como sinónimo de povo português, considerando que para o caso tanto faz um como outro. Percebe-se porquê se tivermos em conta que considera a origem do povo português ancestral, socorrendo-se do etnólogo e arqueólogo Ricardo Severo para a remontar à Pré-História e para defender que constitui uma "unidade perfeita e excepcional"12 Neste sentido, contrariou teses já em curso desde o século XIX que apontavam a grande mescla de povos donde tinham resultado os Portugueses e para o facto de ser impossível estabelecer uma fronteira nítida em relação aos vizinhos da Península Ibérica. João de Barros, partidário de uma linha mais nacionalizadora, optou por afirmar a "individualidade extreme" do povo português e por o associar à velha

9 BRANCO, Camilo Castelo - A rival de Brites de Almeida in PLP, p. 126.

${ }^{10}$ MARTINS, Oliveira - A Maria da Fonte in PLP, p. 144.

${ }^{11}$ BARROS, João de - Advertência in PLP, p. 5.

${ }^{12}$ BARROS, João de - O povo na Literatura Portuguesa. Lisboa: Edição da Sociedade de Instrução e Beneficência “A Voz do Operário”, 1931, Citação Ricardo Severo, p. 5. 
Lusitânia, colando-se ao texto do autor já referido - hoje esquecido - sobre as Origens da Nacionalidade Portuguesa. Esse povo foi o responsável pela fundação da nacionalidade e o verdadeiro sujeito da história nacional, seja na dinâmica dos concelhos medievais, na expansão do território e nas navegações que lhe abriram os caminhos dos mares ou na forma como se espalhou pelo mundo e se afirmou como construtor da Civilização. João de Barros era, naturalmente, partidário do discurso sobre a missão civilizadora dos povos europeus, entre os quais colocava de pleno direito os Portugueses.

As qualidades e as virtudes do povo português eram numerosas para João de Barros que, em contrapartida, lhe apontou poucos defeitos e fraquezas, como "os pessimismos doentios e outros desequilíbrios orgânicos", em grande parte devidos a erros tradicionais da educação ${ }^{13}$. Tendo como leitmotiv a preocupação de mostrar as características positivas do povo português, João de Barros seleccionou trechos de trinta e seis autores que abrangem um arco temporal que começa no século XV e termina no século XX. Só o século XVIII não está representado e, claro, a distribuição favorece largamente os autores contemporâneos que representam $83 \%$ do total. Estes nasceram todos no século XIX, se exceptuarmos Garrett que veio à luz em 1799, e muitos deles foram coevos de João de Barros e seus correligionários nas lides políticas e culturais. O mais jovem da selecção era Ferreira de Castro que tinha nascido em 1898, mas a obra fecha com o texto do escritor mais velho, António Arroio, produzido em 1908 para o catálogo de uma exposição nacional realizada no Rio de Janeiro. Entre as ausências é de salientar a de Teixeira de Pascoaes, da Renascença Portuguesa, que depois da obra já citada passou a ser visto como o mentor do saudosismo. Apesar dessa e de outras falhas para as quais o autor adverte logo no início da obra e explica pelas restrições de espaço, é assinalável a diversidade dos textos e dos autores escolhidos: cronistas e historiadores, etnólogos e arqueólogos, ensaístas, dramaturgos, romancistas, poetas compõem uma panóplia variada através da qual João de Barros pretende apresentar os aspectos mais importantes da percepção dos escritores sobre os Portugueses. Todavia, a antologia de João de Barros diz-nos mais sobre quem a fez do que sobre os autores seleccionados e o seu pensamento. Ela é, na

\footnotetext{
${ }^{13}$ BARROS, João de - Prefácio in PLP, p. 30.
} 
verdade, uma escolha de textos que nos elucida sobre a ideia de povo do seu organizador. Por isso, será neste sentido que vamos enunciar em traços largos a representação do povo português que emerge desta obra.

O primeiro aspecto que se destaca nesta selecção é um conjunto de textos que mostram o povo rebelde, insubmisso, levantado contra a tirania e a favor da liberdade. Começa, logo, nos trechos das crónicas de Fernão Lopes em que vemos a arraia-miúda em grande agitação contra o rei D. Fernando por ir casar com uma mulher que não era digna da sua condição régia. E, no trecho seguinte, da crónica de D. João I, vemos esse mesmo povo a aclamar o Mestre de Avis defensor do Reino, contra a opinião dos grandes e poderosos. Os ventres-ao-sol davam, assim, também uma lição de patriotismo, porque resistiam às pretensões do rei de Castela que se achava com direito de sucessão ao trono. No Arco de Sant 'Ana, do escritor Almeida Garrett, o povo reage conta a tirania do Bispo, senhor da região do Porto, que o esmagava com impostos e prepotências através de uma sublevação geral. Mais adiante, é Oliveira Martins que relata, em páginas exaltadas, a revolta no Minho contra a proibição do enterramento nas igrejas e contra a ditadura de Costa Cabral.

O monárquico Carlos Malheiro Dias também aparece na antologia, mas num excerto de um romance em que evoca a revolta do 31 de Janeiro, no Porto. Esta jornada foi a primeira tentativa, mal sucedida, dos republicanos para derrubar a monarquia. Nas páginas de Malheiro Dias, a multidão aclama a República e canta A Portuguesa pelas ruas. As "ondas de populacho" - na expressão do escritor - cresciam a todo o momento, gritando, barafustando, como se estivessem todos tomados por uma "epidémica loucura". O "formigueiro humano" vai avançando e ouve-se, ao longe, ressoar a estrofe do futuro hino nacional: "Levantai hoje de novo/ O esplendor de Portugal". As palavras de Malheiro Dias não podiam ser mais irónicas, mas para João de Barros o exemplo estava ali naquela multidão amotinada a defender um novo regime. Por sua vez, do escritor Júlio Dantas temos um excerto da obra A Pátria Portuguesa onde o herói é um jovem caldeireiro que fazia parte das forças de que os republicanos dispunham para zelar pela legalidade do acto eleitoral. Numa altercação violenta, acaba morrendo fulminado pelas balas da polícia a defender a urna lacrada contra aqueles que queriam viciar o sufrágio. Do romance de Ferreira de Castro, Eternidade, é extraída 
a descrição de uma revolta popular que ocorreu no Funchal, movida pelo grito colectivo do povo madeirense que andava esfomeado e queria pão.

Não é, decerto, por acaso que João de Barros escolhe todos estes episódios, entre o real e o ficcionado, para a antologia sobre o povo português. Eles servem para mostrar a tese do amor do povo pela liberdade, pela justiça e a sua capacidade para enfrentar as tiranias. A lição a tirar para o presente que então se vivia e para o regime ditatorial era por demais evidente. Numa ordem de ideias equivalente a esta no pensamento de Barros, vemos também o povo a lutar contra os invasores, contra os inimigos externos da nação, dominado pelo fervor patriótico. Para ilustrar esta visão seleccionou autores conceituados como o Padre António Vieira, o historiador Alexandre Herculano, o romancista Camilo Castelo Branco e o jornalista Joaquim Manso, que durante mais de três décadas foi director do Diário de Lisboa. Obviamente, o principal inimigo era a coroa de Castela que queria cercear a independência dos Portugueses e, por extensão, os castelhanos ou, indistintamente, os espanhóis que invadiam o território da nação. Como é conhecido, as ideologias nacionalistas precisam de um inimigo externo para rivalizar e afirmar a independência, a soberania e a identidade nacional, o que é feito sempre por oposição a outra nação. Se podemos remontar os sentimentos anti-castelhanos às crónicas de Fernão Lopes e eles perpassam vários momentos da história da época moderna, mormente no chamado período filipino, é no século XIX que, com a criação da Sociedade Histórica da Independência Nacional e com o Monumento aos Restauradores, no centro de Lisboa, a retórica nacionalista passou a não dispensar a referência ao $1^{\circ}$ de Dezembro de 1640 e ao exemplo que foi dado pelos antepassados que lutaram pela autonomia de Portugal.

$\mathrm{O}$ outro conjunto de textos que sobressai na antologia refere-se à labuta pela vida, em condições duras e miseráveis, sem que o povo perca a simplicidade, a pureza e a alegria. Desenrolam-se, por isso, perante os nossos olhos cenas das fainas em terra e no mar, e o cortejo da pobreza, da dor, da rude existência é mitigado pelas festas e as romarias. O povo não se rende, não desiste, e, nas suas cabanas nuas, os pobres ainda pensam que há quem seja mais desafortunado do que eles ${ }^{14}$ : São seres afeitos aos caminhos agrestes,

\footnotetext{
${ }^{14}$ BRANDÃO, Raúl - Os pobres in PLP, p. 187.
} 
rijos, fortes, trabalhadores, incansáveis, em que há também numa nota de galhardia e valentia. E o melhor exemplo disso vem das ilhas dos Açores, com as toiradas da ilha Terceira e a caça ao cachalote nas ilhas do Faial e do Pico. O homem enfrenta as alimárias embravecidas de braços nus e peito aberto, e o professor e jornalista Luís da Câmara Reis, do grupo que fundou a Seara Nova, comenta: "Touradas em terra, touradas no mar..."15. Os exemplos de força física e moral abundam, mas o caso quiçá mais comovente é descrito pela pena do poeta neo-romântico Augusto Gil, com o sugestivo título: "O pobrezinho honrado" ${ }^{16}$. É a história de um rapazito que vendia cautelas pelas ruas da Baixa lisboeta, a quem o autor passa a mimar com colheres de açúcar, um verdadeiro luxo para o pobre, e uns vinténs que este só aceita nos dias em que não consegue vender a sua "fazenda". Vivo e esperto, o rapaz tornou-se uma figura presente no quotidiano do poeta até que desapareceu. Roído pela saudade, ainda procurou e perguntou por ele, mas só uns meses depois soube pelo pai que o pequeno morrera de enterite. Também num célebre poema sobre a neve, que todos nós aprendemos a declamar na escola, o poeta se condoía com a sorte das crianças cujos pequenos pés, "descalcinhos e doridos", pisavam os gélidos caminhos. Mas nem só de tristeza se constrói a imagem da vida do povo, há a festa, a alegria ruidosa, picaresca e vivaz dos múltiplos folguedos que se desenrolam ao longo do ano. Para ilustrar essa faceta dos Portugueses, João de Barros recorreu ao escritor Teixeira de Queirós, que também era seu sogro, e à narrativa das festas minhotas ${ }^{17}$.

Outro aspecto distinto da maneira de ser dos Portugueses prende-se com a inclinação amorosa, a sensibilidade à flor da pele e o lirismo que está presente no cancioneiro popular e na literatura. O texto fundamental nesta matéria é o do Teófilo Braga, republicano e figura multifacetada de autodidacta e intelectual, que foi fundador da história da literatura portuguesa. Neste excerto, dissertou sobre o carácter amoroso dos portugueses, patente desde a época medieval na literatura portuguesa - de que é expoente máximo o Amadis de Gaula-, e reconhecido por autores estrangeiros, como Cervantes, Lope de Vega, Madame de Sévigné e Balzac, para só referir alguns do que

\footnotetext{
${ }^{15}$ REYS, Luís da Camara - O Povo dos Açores in PLP, p. 261.

${ }^{16}$ GIL, Augusto - O pobrezinho, honrado in PLP, p. 233.

${ }^{17}$ QUEIROZ, Teixeira de - Festa Minhota in PLP, p. 157.
} 
cita em abono da sua tese ${ }^{18}$. Aliás, uma ideia que encontramos noutros trechos seleccionados por João de Barros, sob múltiplas formas: na farsa do escudeiro sempre enamorado, na tragédia sobre Inês de Castro, de António Ferreira, na lírica de João de Deus, que exalta o amor materno, e em diversas abordagens sobre a "alma nacional". Nesta linha, o escritor Ramalho Ortigão escreveu que o Português era célebre em Espanha, no século XVII, pela sua melosidad y derretimiento en amores ${ }^{19}$. E Afonso Lopes Vieira foi buscar uma quadra do cancioneiro popular português, traduzida para inglês por Lord Byron, que é, na sua opinião, "a que melhor traduz o arranque da alma amorosa para o infinito": Chamaste-me tua vida / e eu tua alma quero ser: I a vida acaba co'a morte / a alma não pode morrer ${ }^{20}$.

Finalmente, a representação do povo português não ficaria completa sem um aspecto que, tendo como paradigmas o poeta Camões e o autor da Peregrinação, Fernão Mendes Pinto, desde o século XIX aparece como um traço marcante das idiossincrasias nacionais: a alma de viajantes, o apelo da aventura e do mar, a par da proverbial capacidade de adaptação dos Portugueses a diferentes ambientes. António Nobre pede a Georges, no poema Lusitânia no Bairro Latino, "anda ver o meu país de Marinheiros"21. O poema de Henrique Lopes de Mendonça, escrito numa época de grande exaltação anti-britânica, em 1890, depois adoptado pelo regime republicano como hino nacional, repete o refrão: Heróis do mar, nobre povo. Homens do mar, os Portugueses estão sempre a partir e a espalhar-se por várias partes do mundo. E Ramalho Ortigão, grande observador dos costumes nacionais, tem a "impressão que os portugueses precisam de emigrar para desenvolverem todos os recursos da sua nativa e latente capacidade..."22. Ao mesmo tempo, o Português manifesta um grande "poder de adaptabilidade", seja nos sertões de África ou nas capitais europeias mais civilizadas.

Só umas décadas mais tarde, o pernambucano Gilberto Freire (1900-1987) iria desenvolver as suas teses no mesmo sentido e defender a capacidade dos Portugueses para se relacionar de modo fraternal com povos

\footnotetext{
${ }^{18}$ BRAGA, Téofilo in PLP, p. 135.

${ }^{19}$ ORTIGÃO, Ramalho - Raça Forte in PLP, 138.

${ }^{20}$ PLP, p. 232.

${ }^{21}$ PLP, p. 179.

${ }^{22}$ PLP, 141.
} 
estranhos. Encontramos eco dessas ideias no prefácio de João de Barros à antologia que não estavam ainda presentes na conferência, em 1931, por ser anterior à recepção das primeiras obras do sociólogo brasileiro em Portugal. Refere, nesta óptica, que os Portugueses foram sempre capazes de "entender-se, fraternizar, viver amistosamente com as mais variadas gentes do globo", revelando um "espírito universalista" ${ }^{23}$. Estas ideias iriam ter uma grande fortuna no quadro da retórica política nacionalista que servia para justificar a continuidade do Império português e a negação da independência às colónias, a qual não foi exclusiva dos conservadores nem do regime salazarista.

Em suma, os textos de João de Barros sobre o povo português não se distinguem pela originalidade das suas interpretações, mas por serem uma síntese de ideias difundidas nos meios intelectuais e políticos da época. Por um lado, vimos o cunho republicano e democrático da sua visão do povo, claramente afirmado pela forma como projecta o seu ideário político na representação que construiu através dos seus escritos e dos trechos dos autores que, deliberadamente, escolheu para a antologia. Para João de Barros, o povo português é desde os remotos Lusitanos, seus directos antepassados, apegado a formas de organização republicanas, liberais e mesmo democráticas. $\mathrm{O}$ amor da liberdade e da independência sempre teria sido uma característica da acção popular na história nacional, bem como a capacidade de resistência à tirania. Por outro lado, o povo é portador de grandes qualidades e virtudes que são enaltecidas ao longo de toda a obra. Mas o texto do escritor e crítico de arte António Arroio que seleccionou como epílogo é, nesse ponto, muito elucidativo da imagem que quer imprimir no espírito dos leitores. Aquele socorreu-se de um diplomata alemão que esteve em Portugal, o conde de Raczynski, para reiterar que se trata de um povo "inteligente, laborioso, moderado, de carácter bom, doce e alegre"24. E depois de fazer uma digressão pelas várias províncias portuguesas e pelos seus habitantes, em quem procurou surpreender características peculiares, acabou a afirmar que em todas as terras encontrou o mesmo fundo do carácter do povo português que já tinha sido apontado pelo conde alemão, aos quais acrescentou a "resignação, lealdade e sobriedade" e a "maleabilidade de

\footnotetext{
${ }^{23}$ PLP, p. 39.

${ }^{24}$ PLP, p. 298-299.
} 
adaptação", com a excepção do homem do Baixo Alentejo devido a factores geográficos e socioeconómicos. Concluiu o seu testemunho, escrito em 1908, afirmando que só a influência nefasta das "classes dirigentes" ou a abstenção por parte das "classes superiores" de exercerem uma acção benéfica podia explicar o estado de "estacionamento" da sociedade portuguesa ${ }^{25}$. É evidente que João de Barros compartilhava desta tese e queria com este final deixar um aviso sobre a responsabilidade das elites portuguesas no estado da nação.

${ }^{25}$ PLP, p. 307. 